\title{
POLA MAKAN DAN AKTIVITAS FISIK REMAJA AKHIR DENGAN RIWAYAT DIABETES DI YOGYAKARTA
}

\section{Diet and Physical Activity among Late Adolescence with Diabetes Family History in Yogyakarta}

\author{
Juniar Ayuning Wigiyandiaz ${ }^{1}$, Martalena Br. Purba ${ }^{2}$, Retna Siwi Padmawati ${ }^{3}$ \\ ${ }^{1}$ Pascasarjana IImu Kesehatan Masyarakat, Fakultas Kedokteran Kesehatan Masyarakat dan \\ Keperawanan, Universitas Gadjah Mada \\ 2Instalasi Gizi RSUP Dr. Sardjito, Yogyakarta \\ ${ }^{3}$ Departemen Perilaku Kesehatan, Lingkungan dan Kedokteran Sosial, Fakultas Kedokteran Kesehatan \\ Masyarakat dan Keperawatan, Universitas Gadjah Mada \\ E-mail: juniardiaz@gmail.com
}

\begin{abstract}
The risk of diabetes will increase when there was any diabetes family history. The study aimed to determine the relationship of having diabetes family history with diet and physical activity among late adolescents. This study also determines the factors that influence diet and physical activity. This study was a mixed-method, which was done in two phases, quantitative followed by a qualitative study. Fifty late-adolescent (18-24 years old) involved in the quantitative study, and fourteen late-adolescent involved in the qualitative study. The subject for the quantitative study was a family member of the Chronic Disease Program in (Prolanis) in Puskesmas study area. The selection of fourteen subjects for qualitative study was proportionally based on variations arise from the quantitative study. The study showed that there was no significant association between life with diabetes family members in one home or not with diet and physical activity $(p=0,310$ dan $p=0,297)$. Nor was there any association between having diabetes family history from first or second relative's degree with diet and physical activity $(p=0,276$ dan $p=0,547)$. There was 92 percent of respondents had low fiber, high fat, and high sugar diet. This study found that factors influenced diet and physical activity were perceive susceptibility, perceived benefit, perceived barrier, and self-efficacy. There was no association between having diabetes family history with diet and physical activity. Support from family, friends, work environment or campus is needed to establish a healthy diet and physical activity, to prevent diabetes.
\end{abstract}

Keywords: diabetes, family history, late-adolescence, diet, physical activity

\section{ABSTRAK}

Riwayat keluarga dengan diabetes dapat meningkatkan risiko seseorang mengalami diabetes. Penelitian ini bertujuan untuk mengetahui hubungan memiliki riwayat keluarga diabetes dengan pola makan dan aktivitas fisik remaja akhir, serta mengetahui faktor-faktor yang dapat mempengaruhi pola makan dan aktivitas fisik tersebut. Penelitian ini merupakan penelitian mixed method yang dilakukan dalam dua tahap, yaitu penelitian kuantitatif diikuti penelitian kualitatif. Sebanyak lima puluh remaja akhir (usia 18-24 tahun) terlibat dalam penelitian kuantitatif, dan empat belas remaja akhir terlibat dalam penelitian kualitatif. Hasil penelitian menunjukkan bahwa tidak terdapat hubungan signifikan antara tinggal satu rumah dan tidak satu rumah dengan anggota keluarga penyandang diabetes terhadap pola makan dan aktivitas fisik $(p=0,310$ dan $p=0,297)$. Tidak pula terdapat hubungan antara memiliki riwayat keluarga diabetes dari keluarga inti atau keluarga besar terhadap pola makan dan aktivitas fisik $(p=0,276$ dan $p=$ 0,547 ). Hasil penelitian juga menemukan bahwa faktor yang mempengaruhi pola makan dan aktivitas fisik antar lain persepsi kerentanan, persepsi manfaat, persepsi hambatan, serta kemampuan diri. Kesimpulan dari penelitian ini bahwa tidak terdapat hubungan antara memiliki riwayat keluarga diabetes terhadap pola makan dan aktivitas fisik remaja akhir yang memiliki riwayat keluarga diabetes. Dukungan dari keluarga, pertemanan, lingkungan kerja atau kampus diperlukan untuk membentuk pola makan dan aktivitas fisik yang sehat, untuk mencegah diabetes.

Kata kunci: diabetes, riwayat keluarga, remaja akhir, pola makan, aktivitas fisik 


\section{PENDAHULUAN}

$\mathrm{D}$ iabetes merupakan penyakit tidak menular yang sering dihubungkan dengan faktor keturunan, namun sesungguhnya diabetes memiliki faktor risiko yang dapat diubah seperti pola makan dan aktivitas fisik. ${ }^{1}$ Berdasarkan data Riskesdas (2013) diketahui bahwa Indonesia sudah memiliki prevalnsi diabetes sebesar 6,9 persen, dengan Yogyakarta sudah memiliki prevalensi diabetes sebesar 2,6 persen bagi yang terdiagnosa oleh Dokter. Jumlah ini bisa menjadi lebih banyak, mengingat tidak semua masyarakat Indonesia memilih untuk langsung memeriksakan masalah kesehatan di unit pelayanan kesehatan. ${ }^{2,3}$

Remaja akhir (18-24 tahun) merupakan tahap menuju usia dewasa dimana kebiasaan yang salah pada usia ini sering berlanjut hingga usia tua. Periode usia remaja akhir memiliki karakteristik adanya otonomi terhadap diri sendiri dan sudah mulai tinggal terpisah dari orang tua, sehingga kebiasaan seperti pola makan dan aktivitas fisik merupakan hal yang benar-benar dilakukan oleh dirinya sendiri, bukan lagi bergantung pada orang lain. ${ }^{4}$

Sesuai dengan Health Belief Model Theory, seseorang akan merasa lebih rentan terkena penyakit tertentu dan melakukan sesuatu untuk menghindari penyakit tersebut ketika sudah menyadari adanya faktor risiko suatu penyakit dalam dirinya. Tinggal dalam satu rumah dengan anggota keluarga yang menyandang diabetes, atau memiliki tingkat kekerabatan yang dekat dengan penyandang diabetes secara teori dapat menimbulkan kesadaran akan pentingnya pola makan dan aktivitas fisik untuk menghindari diabetes..$^{5,6}$

Teori di atas menggiring kemungkinan adanya perubahan atau keinginan perubahan untuk memiliki pola makan yang lebih sehat atau aktivitas fisik yang lebih baik, ketika seorang remaja mengetahui dan sadar bahwa dirinya memiliki riwayat diabetes dalam keluarga, serta memiliki risiko mengalami diabetes yang lebih besar dibanding teman sebaya mereka. Pola makan serta aktivitas fisik merupakan sesuatu yang membutuhkan dukungan lingkungan, baik dari keluarga, lingkungan pertemanan, hingga tempat bekerja atau kampus. ${ }^{7,8}$
Berdasarkan uraian di atas, peneliti ingin melihat hubungan antara tinggal satu rumah dengan anggota keluarga penyandang diabetes atau tidak tinggal satu rumah, terhadap pola makan dan aktivitas fisik remaja akhir dengan riwayat diabetes di Yogyakarta. Peneliti juga ingin melihat hubungan antara memiliki riwayat keluarga diabetes dari keluarga inti (ayah, ibu atau saudara kandung) dan keluarga besar (kakek, nenek, paman atau bibi) terhadap pola makan dan aktivitas fisik remaja akhir dengan riwayat keluarga diabetes. Dalam penelitian ini, digali juga faktor-faktor apa saja yang dapat mempengaruhi pola makan dan aktivitas fisik remaja akhir dengan riwayat keluarga diabetes di Yogyakarta.

\section{METODE PENELITIAN}

Penelitian mixed method, yang diawali dengan penelitian kuantitatif dan diikuti dengan penelitian kualitatif. Penelitian dilakukan pada bulan Januari hingga April 2018 setelah terbit surat kelayakan etik dengan nomor KE/FK/0061/EC/2018 dari Komisi Etik Fakultas Kedokteran UGM.

Responden penelitian merupakan remaja akhir usia 18-24 tahun yang tinggal di Yogyakarta. Pemilihan subjek diambil dari anak, cucu atau keponakan anggota Prolanis (Program Penyakit Kronis) di puskesmas yang berada di Kota Yogyakarta. Remaja akhir yang mengambil kuliah atau bekerja di bidang kesehatan dan pernah terdiagnosa diabetes tidak diikutsertakan dalam penelitian. Penelitian kualitatif melibatkan lima puluh responden, sedangkan penelitian kualitatif mengambil empat belas responden. Pengambilan responden untuk penelitian kualitatif didasarkan pada variasi yang muncul dari penelitian kuantitatif seperti variasi penghasilan atau uang saku, jumlah anggota keluarga yang terdiagnosa diabetes, kedekatan relatif, tempat tinggal, indeks massa tubuh dan merokok. Responden dalam penelitian kualitatif diambil secara proporsional dari masing-masing variasi yang ditemukan, sehingga bisa mewakili variasi yang muncul dalam penelitian.

Data yang digunakan dalam penelitian kuantitatif merupakan data dasar yang terdiri dari nama, usia, pekerjaan, besar uang saku atau pendapatan, serta indeks massa tubuh yang didapat dari pengukuran berat badan 
menggunakan timbangan digital dan pengukuran tinggi badan menggunakan mikrotoise. Data pola makan dikumpulkan dari pengisian food record secara mandiri oleh responden selama enam hari, serta data aktivitas fisik yang didapat dari wawancara peneliti kepada responden menggunakan International Physical Activity Questionnaire (IPAQ) selama dua minggu berturut-turut, sesuai dengan protokol IPAQ. Sebelum mengisi food record, peneliti memberi tahu cara pengisian food record oleh responden, sehingga dapat mengurangi kesalahan pengisian. Makanan yang dicatat merupakan seluruh makanan yang dikonsumsi, baik makanan utama, makanan selingan maupun minuman.

Pola makan dikategorikan sebagai sehat apabila total kalori dan lemak sesuai anjuran angka kecukupan gizi, asupan gula sederhana $\leq 25$ gram per hari, dan asupan serat $\geq 25$ gram per hari. Pola makan dikategorikan tidak sehat jika asupan kalori dan lemak lebih dari angka kecukupan gizi, asupan gula sederhana lebih dari 25 gram per hari, dan asupan serat kurang dari 25 gram per hari. 1,9,10 Pengukuran aktivitas fisik mengikuti pembagian skor IPAQ, aktivitas fisik akan dikategorikan sebagai rendah jika skor IPAQ kurang dari 600 METs per minggu, kategori sedang jika skor IPAQ berkisar 600-3000 METs per minggu, dan kategori tinggi jika skor IPAQ lebih dari 3000 METs per minggu. ${ }^{11}$

Wawancara mendalam digunakan dalam pengambilan data penelitian kualitatif. Dalam penelitian ini juga dilakukan wawancara berdasarkan General Nutrition Knowledge Questionnaire (GNKQ) untuk mengetahui bagaimana pengetahuan responden terhadap gizi dan kesehatan. Pertanyaan yang ditanyakan saat wawancara mendalam meliputi hubungan kekerabatan dengan penyandang diabetes, apakah terlibat dalam proses pengobatan anggota keluarga, apakah terdapat perubahan pola makan dan aktivitas fisik dari anggota keluarga dan dirinya sendiri, hal apa saja yang sudah dilakukan responden untuk mengurangi risiko diabetes, apakah responden merasa memiliki faktor risiko diabetes selain riwayat keluarga, dan bagaimana pola makan yang sehat serta aktifitas fisik yang baik menurut responden.

Triangulasi dilakukan dari data penelitian kuantitatif, hasil pengetahuan mengenai nutrisi dari GNKQ, dan hasil wawancara mendalam. Analisis data secara kuantitatif dilakukan dengan menggunakan Chi-square test atau Fisher's exact test jika terdapat sel yang memiliki nilai ekspektasi kurang dari lima. Analisis data pada penelitian kualitatif menggunakan pendekatan grounded analysis dengan pemberian kode pada hasil wawancara, penamaan kategori, penyusunan kategori dan tema, serta analisis secara objektif dan sistematis sebelum pengambilan kesimpulan.

\section{HASIL}

Karakteristik responden ditampilkan pada Tabel 1. Sebagian besar responden masih berstatus mahasiswa, dengan uang saku atau penghasilan lebih banyak berada dibawah $\mathrm{Rp}$ 1.500.000,- karena responden masih menerima uang saku dari orang tua atau baru saja bekerja sehingga baru mendapatkan penghasilan sebesar atau lebih kecil dari upah minimum regional (UMR) di Yogyakarta.

Sebagian besar responden memiliki pola makan tidak sehat yang disebabkan pola makan rendah serat, tinggi gula sederhana dan tinggi lemak. Terdapat sepertiga responden yang memiliki aktivitas fisik rendah atau sedentary, dan tidak ada responden yang memiliki tingkat aktivitas fisik yang tinggi. Dari hasil di atas dapat dilihat bahwa pola makan dan aktivitas fisik responden sebagian besar masih belum sehat.

Berdasarkan wawancara mendalam, responden yang memiliki uang saku atau penghasilan lebih dari $\mathrm{Rp} 1.500 .000$,- lebih sering berkumpul dengan teman di kafe dimana responden akan mengkonsumsi makanan cepat saji, juga tinggi lemak dan gula. Responden yang memiliki uang saku dibawah $R p$ 1.500.000,- cenderung memilih makanan dengan harga murah dan memiliki porsi yang besar, serta tidak mempertimbangkan kesehatan dalam memilih makanan. Hasil wawancara mendalam juga menyatakan bahwa ketika responden berada di rumah, responden akan mengikuti pola makan di rumah yang dianggap sehat, namun tidak menerapkan pola makan tersebut ketika makan di luar dengan teman.

"Makan yang sehat? Ya paling di rumah aja sih Mba. Kalau pas lagi sama teman ya 
biasa aja makannya. Apa yang ada ya dimakan. Soalnya kalau tahu-tahu makan yang ngga sehat apa ngga minum yang manis ntar disangka gimana-gimana, malah kena ledek," (perempuan, riwayat diabetes dari keluarga inti, tinggal satu rumah dengan penyandang diabetes).

Berdasarkan Tabel 2 dan 3 diketahui bahwa tidak terdapat hubungan signifikan antara tinggal satu rumah dan tidak tinggal satu rumah dengan anggota keluarga penyandang diabetes terhadap pola makan dan aktivitas fisik responden $(p=0,310$ dan $p=0,297)$. Tidak terdapat pula hubungan signifikan antara memiliki riwayat keluarga diabetes dari keluarga inti atau keluarga besar terhadap pola makan dan aktivitas fisik responden $(p=0,276$ dan $p=$ $0,547)$.

Tabel 1

Karakteristik Dasar Responden dan Gambaran Pola Makan serta Aktivitas Fisik Responden

\begin{tabular}{|c|c|c|c|c|}
\hline Karakteristik & $\mathrm{N}$ & $\%$ & Mean & SD \\
\hline \multicolumn{5}{|l|}{ Jenis Kelamin } \\
\hline Perempuan & 30 & 60 & & \\
\hline Laki-laki & 20 & 40 & & \\
\hline \multicolumn{5}{|l|}{ Riwayat Keluarga } \\
\hline Keluarga Inti & 21 & 42 & & \\
\hline Keluarga Besar & 29 & 58 & & \\
\hline \multicolumn{5}{|c|}{ Tinggal Satu Rumah dengan Anggota Keluarga } \\
\hline \multicolumn{5}{|c|}{ Penyandang Diabetes } \\
\hline $\mathrm{Ya}$ & 14 & 28 & & \\
\hline Tidak & 36 & 72 & & \\
\hline \multicolumn{5}{|l|}{ Indeks Massa Tubuh } \\
\hline Gizi Kurang (Underweight) & 5 & 10 & & \\
\hline Normal & 30 & 60 & & \\
\hline Gizi Lebih (Overweight) & 5 & 10 & & \\
\hline Obesitas & 10 & 20 & & \\
\hline \multicolumn{5}{|l|}{ Pekerjaan } \\
\hline Mahasiswa & 40 & 80 & & \\
\hline Bekerja & 10 & 20 & & \\
\hline \multicolumn{5}{|l|}{ Penghasilan atau Uang Saku } \\
\hline$<\operatorname{Rp} 1,500,000,-$ & 37 & 74 & & \\
\hline$\geq \operatorname{Rp} 1,500,000$ & 13 & 26 & & \\
\hline \multicolumn{5}{|l|}{ Pola Makan } \\
\hline Sehat & 4 & 8 & & \\
\hline Tidak Sehat & 46 & 92 & & \\
\hline \multicolumn{5}{|l|}{ Aktivitas Fisik } \\
\hline Rendah & 19 & 38 & & \\
\hline Sedang & 31 & 62 & & \\
\hline Tinggi & 0 & 0 & & \\
\hline \multicolumn{5}{|l|}{ Pola Makan Tidak Sehat } \\
\hline Rendah Serat (gram) & 45 & 90 & 11,42 & 5,57 \\
\hline Tinggi Gula Sederhana (gram) & 27 & 54 & 30,89 & 17,54 \\
\hline Tinggi Lemak (gram) & 13 & 26 & 70,59 & 23,06 \\
\hline Tinggi Kalori (Kkal) & 2 & 4 & 1880,76 & 291,62 \\
\hline
\end{tabular}


Tabel 2

Hubungan Tempat Tinggal dengan Pola Makan dan Aktivitas Fisik Responden

\begin{tabular}{|c|c|c|c|c|c|c|c|}
\hline \multirow{3}{*}{ Kategori } & \multicolumn{4}{|c|}{ Pola Makan } & \multirow[b]{3}{*}{$p$} & \multirow[b]{3}{*}{$O R$} & \multirow[b]{3}{*}{$95 \% \mathrm{Cl}$} \\
\hline & \multicolumn{2}{|c|}{ Sehat } & \multicolumn{2}{|c|}{ Tidak Sehat } & & & \\
\hline & $\mathrm{N}$ & $\%$ & $\mathrm{~N}$ & $\%$ & & & \\
\hline \multicolumn{8}{|l|}{ Tempat Tinggal } \\
\hline Tinggal Satu Rumah & 2 & 4 & 12 & 24 & 0,310 & 2,833 & $0,446-18,052$ \\
\hline Tidak Tinggal Satu Rumah & 2 & 4 & 34 & 68 & & & \\
\hline \multicolumn{8}{|l|}{ Kedekatan Relatif } \\
\hline Keluarga Inti & 3 & 6 & 18 & 36 & 0,297 & 0,214 & $0-1,163$ \\
\hline Keluarga Besar & 1 & 2 & 28 & 56 & & & \\
\hline
\end{tabular}

Tabel 3

Hubungan Kedekatan Relatif dengan Pola Makan dan Aktivitas Fisik Responden

\begin{tabular}{|c|c|c|c|c|c|c|c|}
\hline \multirow{3}{*}{ Kategori } & \multicolumn{4}{|c|}{ Aktivitas Fisik } & \multirow[b]{3}{*}{$p$} & \multirow[b]{3}{*}{$O R$} & \multirow[b]{3}{*}{$95 \% \mathrm{Cl}$} \\
\hline & \multicolumn{2}{|c|}{ Rendah } & \multicolumn{2}{|c|}{ Sedang } & & & \\
\hline & $\mathrm{N}$ & $\%$ & $\mathrm{~N}$ & $\%$ & & & \\
\hline \multicolumn{8}{|l|}{ Tempat Tinggal } \\
\hline Tinggal Satu Rumah & 7 & 14 & 7 & 14 & 0,276 & 0,500 & $0,146-1,699$ \\
\hline Tidak Tinggal Satu Rumah & 12 & 24 & 24 & 48 & & & \\
\hline \multicolumn{8}{|l|}{ Kedekatan Relatif } \\
\hline Keluarga Inti & 9 & 18 & 12 & 24 & 0,547 & 1,425 & $0,458-4,444$ \\
\hline Keluarga Besar & 10 & 20 & 19 & 38 & & & \\
\hline
\end{tabular}

\begin{tabular}{|c|c|c|}
\hline Faktor Modifikasi & Kepercayaan Individual & Aksi \\
\hline $\begin{array}{l}\text { - Uang saku atau } \\
\text { penghasilan } \\
\text { - Pengetahuan }\end{array}$ & $\begin{array}{l}\text { Persepsi Kerentanan (Perceived Susceptibility): } \\
\text { Perasaan rentan terkena diabetes karena keturunan dan berat badan } \\
\text { berlebih. } \\
\text { Persepsi Manfaat (Perceived Benefit): } \\
\text { Pola makan seimbang mengurangi risiko diabetes } \\
\text { Persepsi Hambatan (Perceived Barrier): } \\
\text { Faktor individu: } \\
\text { Persepsi rasa makanan, pemilihan atau preferensi makanan, } \\
\text { tidak terbiasa makan teratur, rasa malas, dan tidak } \\
\text { memperhatikan kesehatan. } \\
\text { Lingkungan sosial: } \\
\text { TInggal di kost, tidak ada dukungan dari keluarga dan teman, } \\
\text { dianggap aneh jika mengkonsumsi makanan sehat. } \\
\text { Lingkungan fisik: } \\
\text { Ketersediaan dan harga makanan di Yogyakarta. } \\
\text { Kemampuan Diri (Self efficacy): } \\
\text { Keterampilan memasak, terbiasa makan di rumah dan makan } \\
\text { teratur, bisa mengendalikan diri, dapat menemukan makanan sehat } \\
\text { dengan harga yang murah. }\end{array}$ & Pola Makan Seimbang \\
\hline
\end{tabular}

Gambar 1

Faktor-faktor yang Mempengaruhi Pola Makan 
Terdapat faktor yang mempengaruhi pola makan seperti persepsi kerentanan akan terdiagnosa diabetes karena memiliki riwayat keluarga diabetes dan memiliki berat badan berlebih. Timbul pula persepsi bahwa pola makan yang sehat dapat menurunkan risiko diabetes.

"Wah iya, waktu pertama kali tahu mama kena gula, jadi takut banget. Apalagi saya kan gemuk ya, sama kayak mama. Makanan yang dimakan sama. Kalau ada camilan juga saya pasti ikut makan," (perempuan, riwayat diabetes dari keluarga inti, tinggal satu rumah dengan penyandang diabetes)

Persepsi lain yang dapat menguatkan responden untuk memiliki pola makan yang sehat juga dapat berasal dari persepsi mengenai kemampuan diri, diantaranya keterampilan memasak, terbiasa makan di rumah dan makan secara teratur, kemampuan untuk mengendalikan diri untuk menghindari konsumsi makanan yang tidak sehat, dan mampu menemukan makanan sehat dengan harga yang lebih murah seperti sayuran dan buah musiman.

"Ibu sekarang sering beli buah musiman Mba, kan harganya lebih murah," (perempuan, riwayat diabetes dari keluarga inti, tidak tinggal satu rumah dengan penyandang diabetes)

Persepsi hambatan merupakan persepsi yang membuat responden tidak menerapkan pola makan yang sehat. Hambatan yang dapat muncul dapat berupa faktor individu, lingkungan sosial dan lingkungan fisik. Hambatan dari faktor individu dapat berupa persepsi terhadap rasa makanan atau menganggap makanan sehat memiliki rasa tidak enak, pemilihan atau preferensi makanan, tidak terbiasa makan teratur, rasa malas untuk mendapatkan makanan sehat dan belum peduli dengan kesehatan. Hambatan dari lingkungan sosial antara lain tinggal di tempat kost, tidak ada dukungan untuk mengkonsumsi makanan sehat dari teman atau keluarga dan merasa dianggap aneh jika mengkonsumsi makanan sehat.
Hambatan dari lingkungan fisik antara lain ketersediaan dan harga makanan.

"Susah Mba kalau anak kost disuruh makan yang sehat. Makan kaya gitu bisanya di rumah. Kalau di kost pasti beli, soalnya ngga ada dapur buat masak sama kulkas buat naruh-naruh makanan biar ngga cepat basi," (perempuan, riwayat diabetes dari keluarga besar, tidak tinggal satu rumah dengan penyandang diabetes)

Aktivitas fisik juga dipengaruhi oleh persepsi kerentanan dan persepsi manfaat yang sama seperti pola makan. Persepsi hambatan untuk melakukan aktivitas fisik yang sehat dari faktor individu dapat berupa belum memperhatikan kesehatan, tidak memiliki keterampilan atau tidak terbiasa berolahraga, rasa ngantuk dan malas untuk berolahraga, serta badan yang terasa sakit setelah berolahraga. Hambatan dari lingkungan sosial antara lain tidak memiliki waktu untuk berolahraga karena merasa sudah sibuk bekerja atau kuliah dan tidak ada keharusan berolahraga di kantor atau di kampus. Hambatan dari lingkungan fisik dapat berupa fasilitas olahraga yang jauh dari tempat tinggal, kantor atau kampus, masih belum banyak fasilitas olahraga khusus perempuan, dan cuaca yang bisa menghambat kegiatan olahraga terutama di luar ruangan (outdoor).

"Capek kalau habis pulang kantor, jadi ngga olahraga," (laki-laki, riwayat diabetes dari keluarga inti, tidak tinggal satu rumah dengan penyandang diabetes)

Kemampuan diri yang dapat menumbuhkan aktivitas fisik yang sehat antara lain adanya fasilitas olahraga yang terawat dan terjangkau, adanya aplikasi pendukung aktivitas fisik pada telepon seluler, adanya kegiatan olahraga di kampus atau kantor, dan memiliki keterampilan olahraga.

"Saya memang hobi kalau olahraga, jadinya udah biasa aja. Biasanya kalau ngga renang ya futsal apa basket," (lakilaki, riwayat diabetes dari keluarga inti, tidak tinggal satu rumah dengan penyandang diabetes) 


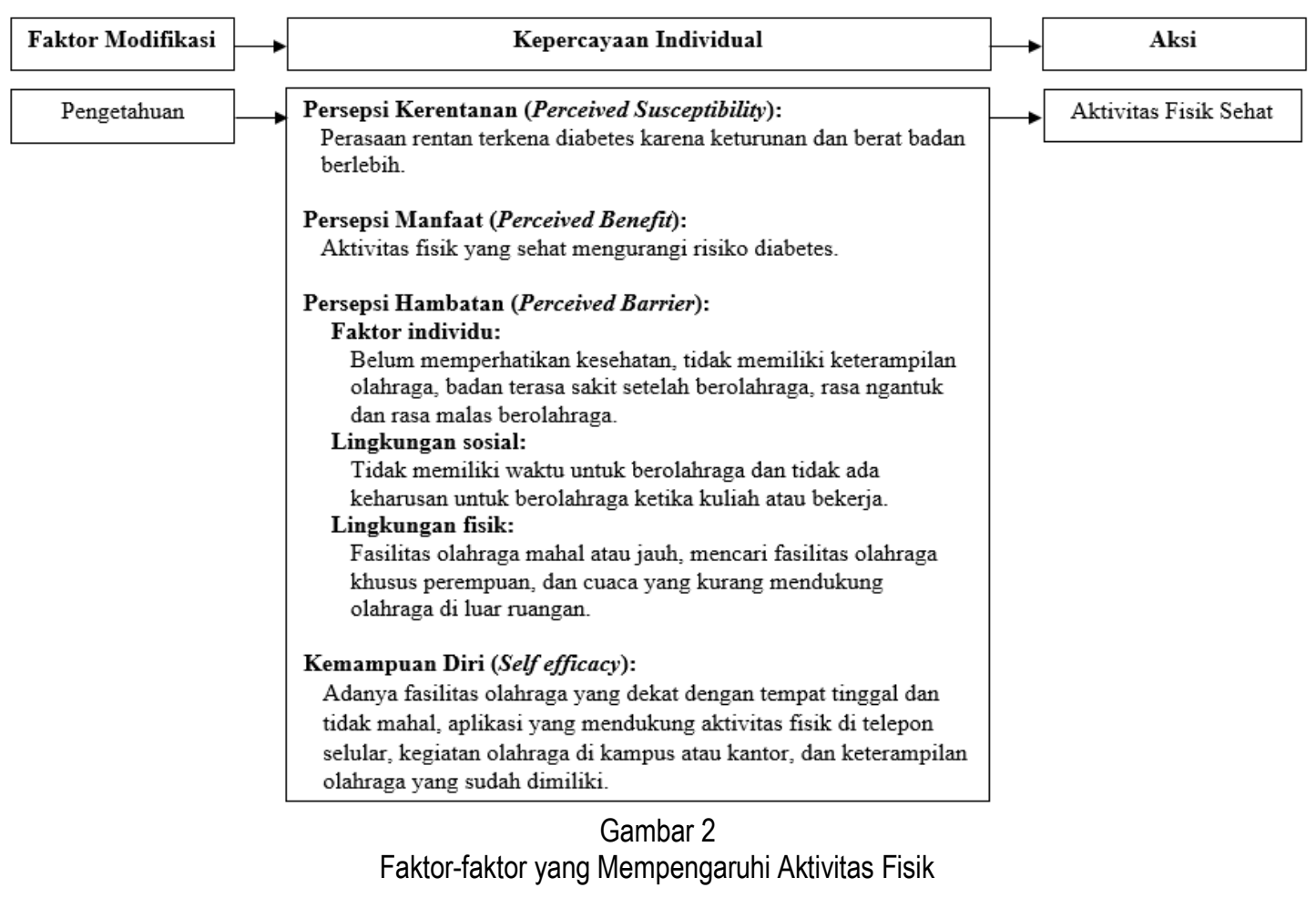

\section{BAHASAN}

Walaupun responden mengetahui bahwa dirinya memiliki riwayat keluarga diabetes dan merasa lebih rentan terkena diabetes dibanding teman sebayanya yang tidak memiliki riwayat keluarga diabetes, namun hal tersebut tidak serta-merta membuat responden memiliki pola makan dan aktivitas fisik yang sehat. Beberapa responden hanya mengikuti pola makan sehat di rumah, namun tidak melakukan hal tersebut ketika makan di luar bersama teman. Hal ini disebabkan oleh banyaknya persepsi hambatan yang dirasakan responden ketika ingin menerapkan pola makan dan aktivitas fisik yang sehat. Hambatan paling besar yang disebutkan responden adalah tidak adanya dukungan dari teman untuk menerapkan pola makan dan aktivitas fisik yang sehat, serta akses makanan sehat yang dianggap lebih sulit di Yogyakarta.

Usia muda seringkali belum mempertimbangkan kesehatan dalam pemilihan makanan. Makanan bukan hanya dikaitkan dengan rasa lapar dan kesehatan, namun juga dijadikan alat untuk berkumpul dan komunikasi, hingg suatu kebiasaan dan respon emosi. Makanan sehat seperti buah dan sayur dianggap memiliki rasa yang tawar atau kurang lezat. Penambahan garam pada makanan dan penambahan gula pada minuman menjadi sesuatu yang biasa dilakukan tanpa mempertimbangkan efeknya bagi kesehatan. ${ }^{12,13} \mathrm{Hal}$ inilah yang membuat masyarakat usia muda lebih memilih makanan yang memiliki kandungan gula, garam dan lemak yang tinggi dan cenderung rendah serat.

Pemilihan makanan oleh remaja banyak dipengaruhi oleh rasa, harga, ketersediaan, dan pengaruh orang terdekat. Remaja tidak banyak mempertimbangkan faktor kesehatan dalam pemilihan makanan. ${ }^{14}$ Faktor lain yang dapat mempengaruhi pemilihan makanan remaja adalah keakraban, kenyamanan, kenikmatan makanan, daya pikat makanan (food appeal), dan nilai uang terhadap makanan. ${ }^{15}$ Remaja dan dewasa muda juga akan membentuk kebiasaan makan sesuai dengan orang di sekitar mereka, karena pada fase ini, mereka cenderung menghabiskan waktu bersama dengan orang lain, terutama teman. ${ }^{8}$

Pembentukan pola makan berawal dari keluarga. Membuat anggota keluarga terlibat sedini mungkin dalam proses pemilihan dan persiapan makanan keluarga dapat menumbuhkan kebiasaan mengkonsumsi makanan yang lebih sehat dan keterampilan dalam memilih serta menyiapkan makanan sehat. ${ }^{16}$ Remaja akhir juga sebaiknya ikut terlibat dalam proses edukasi diabetes, sehingga sejak awal sudah mengetahui bahwa diabetes dapat dicegah dengan pola makan dan 
aktivitas fisik yang sehat. Dengan demikian, diharapkan remaja tersebut dapat tetap memilih makanan sehat saat makan di luar bersama teman, serta dapat terbiasa melakukan aktivitas fisik dengan kesadaran untuk mengurangi risiko diabetes. ${ }^{17}$

Tidak terdapat hubungan signifikan antara tinggal satu rumah dan tidak tinggal satu rumah dengan anggota keluarga yang menyandang diabetes terhadap pola makan dan aktivitas fisik responden. Tidak pula terdapat hubungan signifikan antara memiliki riwayat keluarga diabetes dari keluarga inti maupun keluarga besar terhadap pola makan dan aktivitas fisik responden. Penelitian menyebutkan bahwa ketika seseorang memiliki kedekatan relatif yang semakin dekat dengan anggota keluarga penyandang diabetes, serta semakin besar morbiditas anggota keluarga tersebut, persepsi kerentanan akan diabetes akan semakin kuat. ${ }^{6}$ Hal tersebut tidak terjadi dalam penelitian ini, karena terdapat banyak faktor yang dapat mempengaruhi perubahan perilaku menjadu lebih sehat. ${ }^{5}$

Responden menyatakan bahwa mereka memiliki perasaan rentan terkena diabetes karena memiliki riwayat keluarga diabetes dan memiliki berat badan berlebih. Berat badan berlebih juga dipersepsikan didapatkan dari riwayat keluarga. Pola makan seimbang dan aktivitas fisik yang sehat dipersepsikan dapat mengurangi risko terjadinya diabetes. Persepsi hambatan untuk menerapkan pola makan seimbang dan aktivitas fisik yang sehat dapat berasal dari faktor individu, lingkungan sosial dan lingkungan fisik. Kemampuan diri merupakan hal yang dapat mendukung terbentuknya pola makan seimbang dan aktivitas fisik yang sehat.

Menghabiskan lebih banyak waktu dengan anggota keluarga yang menyandang diabetes dapat membuat seseorang mengetahui kesulitan dan perubahan yang terjadi pada anggota keluarga tersebut. Berat badan berlebih juga seringkali dihubungkan dengan risiko diabetes, sehingga pengaturan pola makan dan aktivitas fisik menjadi lebih sehat dipersepsikan dapat mengurangi risiko diabetes. 6,18

Makanan sehat sering dipersepsikan memiliki harga yang mahal sehingga dianggap tidak terjangkau, dan masyarakat menjadi lebih banyak memilih makanan yang tidak sehat karena memiliki harga yang lebih murah. Adanya kafe sebagai yang tempat yang banyak digunakan untuk berkumpul turut andil dalam meningkatkan konsumsi makanan dan minuman tinggi gula serta lemak ${ }^{19,20}$. Penambahan akses makanan sehat dengan harga yang cukup murah dapat meningkatkan konsumsi makanan sehat masyarakat. Penambahan akses makanan ini dapat dimulai dari area kantin sekolah atau universitas dimana menjadi tempat utama anak dan remaja membeli makanan, sehingga anak dan remaja dapat terbiasa mengkonsumsi makanan sehat dan diharapkan dapat membawa kebiasaan tersebut hingga dewasa. ${ }^{21}$

Hambatan aktivitas fisik yang biasa terjadi antara lain tidak adanya fasilitas olahraga, tidak adanya dukungan sosial dari teman atau keluarga untuk berolahraga, serta kesibukan yang membuat seseorang merasa tidak lagi memiliki waktu untuk berolahraga. Dari hambatan yang disebutkan di atas, maka adanya kegiatan olahraga yang diadakan di sekolah, universitas, kantor atau masyarakat dapat menginisiasi keinginan untuk melakukan aktivitas fisik. Fasilitas olahraga yang terawat dan terjangkau dapat mendukung terbentuknya aktivitas fisik yang sehat. ${ }^{22}$

Sama seperti pembentukan pola makan, aktivitas fisik yang sehat juga dapat tercapai jika terdapat dukungan dari lingkungan. Individu yang berada dalam lingkungan pertemanan atau keluarga yang sering melakukan aktivitas fisik akan cenderung melakukan aktivitas fisik teratur. ${ }^{23}$ Fasilitas olahraga yang disediakan oleh lingkungan tempat tinggal, kantor maupun sekolah dapat pula memicu adanya kelompok olahraga yang dapat saling mendukung kegiatan olahraga. Penggunaan aplikasi dalam gawai juga mampu menjadi alat yang mendukung dilakukannya aktivitas fisik, terutama pada aplikasi yang memiliki tujuan yang harus dicapai. ${ }^{22}$

Aktivitas fisik akan lebih mudah dilakukan jika sudah terbiasa. Mereka yang sudah memiliki keterampilan olahraga sejak dini akan cenderung terus berolahraga ketika dewasa. Individu yang merasa tidak memiliki keterampilan olahraga bisa mulai berlatih hingga olahraga bisa menjadi sebuah kebiasaan. Beberapa hal yang dapat menjadi motivasi untuk melakukan aktivitas fisik antara lain rasa senang setelah melakukan aktivitas 
fisik, persepsi tubuh yang sehat atau persepsi badan yang ideal. ${ }^{24}$

Selain beberapa hal di atas, kampanye mengenai pola makan dan aktivitas fisik yang sehat untuk mencegah diabetes perlu digalakkan oleh berbagai pihak, sekolah, kantor, masyarakat serta lembaga kesehatan, sehingga terbentuk persepsi mengenai pentingnya pola makan dan aktivitas fisik yang sehat sejak dini. 25,26

\section{SIMPULAN DAN SARAN}

\section{Simpulan}

Tidak terdapat hubungan signifikan antara memiliki riwayat keluarga diabetes dengan pola makan dan aktivitas fisik remaja akhir yang memiliki riwayat keluarga diabetes di Yogyakarta. Sebagian besar remaja akhir dengan riwayat diabetes di Yogyakarta masih memiliki pola makan dan aktivitas fisik yang tidak sehat. Faktor-faktor yang dapat mempengaruhi pola makan dan aktivitas fisik remaja akhir dengan riwayat keluarga diabetes antara lain persepsi kerentanan, persepsi manfaat, persepsi hambatan yang dapat berasal dari faktor individu, lingkungan sosial dan lingkungan fisik, serta adanya kemampuan diri untuk membentuk pola makan seimbang dan aktivitas fisik yang sehat.

Persepsi kerentanan seperti menyadari memiliki riwayat keluarga dengan diabetes atau memliki berat badan berlebih, serta persepsi kemampuan diri seperti mampu menyiapkan makanan sehat, terbiasa makan di rumah dan makan teratur, mampu mengendalikan diri dan kemampuan menemukan makanan sehat denga harga yang terjangkau mampu menumbuhkan keinginan responden untuk menerapkan pola makan yang sehat. Hambatan yang dirasakan responden untuk menerapkan pola makan sehat adalah persepsi rasa makanan, tidak terbiasa makan teratur, rasa malas, belum memperhatikan kesehatan, tidak bisa menyiapkan makanan sendiri karena tinggal di kost, tidak ada dukungan dari teman dan keluarga, serta ketidak terdiaan makanan yang dianggap sehat di Yogyakarta.

Subjek yang melakukan aktivitas fisik tingkat sedang juga memiliki persepsi diri yang menyadari adanya riwayat diabetes dalam keluarga atau memiliki tubuh gemuk, sehingga terdapat persepsi manfaat bahwa berolahraga mampu menurunkan berat badan sekaligus mencegah terjadinya diabetes. Persepsi kemampuan diri seperti adanya fasilitas olahraga yang dapat dijangkau, adanya aplikasi yang dapat membantu berolahraga, memiliki keterampilan olahraga serta adanya kegiatan olahraga di kampus atau kantor juga dapat menumbuhkan keinginan responden untuk melakukan aktivitas fisik. Persepsi hambatan yang dirasakan responden untuk melakukan aktivitas fisik Antara lain belum memperhatikan kesehatan, tidak memiliki keterampilan olahraga, rasa sakit setelah berolahraga, rasa malas untuk berolahraga, merasa tidak memiliki waktu untuk melakukan aktivitas fisik, tidak memiliki keharusan untuk melakukan aktivitas fisik, dan tidak ada fasilitas olahraga.

\section{Saran}

Dibutuhkan dukungan penuh dari lingkungan seperti lingkungan keluarga, pertemanan, maupun lingkungan kerja atau kampus untuk membentuk pola makan dan aktivitas fisik yang sehat, untuk mencegah diabetes.

\section{RUJUKAN}

1. Soelistijo SA, Novida H, Rudijanto A, Soewondo $P$, Suastika $K$, Manaf $A$, et al. Konsesus Pengelolaan dan Pencegahan Diabetes Melitus Tipe 2 di Indonesia 2015. Pengurus Besar Perkumpulan Endokrinologi Indonesia (PB Perkeni). Jakarta; 2015.

2. Kementerian Kesehatan Republik Indonesia (Kemenkes RI). Riset Kesehatan Dasar. Jakarta: Kemenkes Rl; 2013.

3. Badan Pusat Statistik. Profil Statistik Kesehatan 2019. Jakarta: Badan Pusat Statistik; 2019.

4. Newman BM, Newman PR. Development Through Life: A Psychosocial Approach. Thirteen Edition. Boston: Cengage Learning; 2017.

5. Glanz K, Rimer BK, Viswanath K. Health Behaviour and Health Education. Fourth Edition. Health Education. San Francisco: Jossey-Bass; 2008.

6. Amuta AO, Jacobs W, Barry AE. An Examination of Family, Healthcare Professionals, and Peer Advice on Physical Activity Behaviors Among Adolescents at High Risk for Type 2 Diabetes. Health Communication. 2017;32(7):857-63. Doi: 10.1080/10410236.2016.1177907.

7. Ekawidyani KR, Karimah I, Setiawan B, Khomsan A. Parents' Characteristics, Food 
Habits and Physical Activity of Overweight Schoolchildren In Bogor City, Indonesia. Diversity and Change in Food Wellbeing. 2018;5(1):177-94. Doi: 10.3920/978-908686-864-3.

8. Pelletier JE, Graham DJ, Laska MN. Social Norms and Dietary Behaviors among Young Adults. American Journal of Healthy Behavior. 2014;38(1):144-52.

Doi: 10.5993/AJHB.38.1.15.

9. Kementerian Kesehatan Republik Indonesia (Kemenkes RI). Situasi dan Analisis Diabetes. Jakarta: Pusat Data dan Informasi Kementerian Kesehatan Rl; 2014.

10. Vos MB, Kaar JL, Welsh JA, Van Horn L V., Feig DI, Anderson CAM, et al. Added Sugars and Cardiovascular Disease Risk in Children: A Scientific Statement from the American Heart Association. Circulation. 2017;135(19):1017-34. Doi: $10.1161 / C I R .0000000000000439$.

11. International Physical Activity Questionnaire (IPAQ). Guidelines for Data Processing and Analysis of the International Physical Activity Questionnaire ( IPAQ ) - Short and Long Forms. IPAQ; 2005.

12. Kourouniotis S, Keast RSJ, Riddell LJ, Lacy K, Thorpe MG, Cicerale S. The Importance of Taste on Dietary Choice, Behaviour and Intake in a Group of Young Adults. Appetite. 2016;103(1):1-7.

Doi: 10.1016/j.appet.2016.03.015

13. Lee $L T$, Willig $A L$, Agne $A A$, Locher JL, Cherrington AL. Challenges to Healthy Eating Practices: A Qualitative Study of Non-Hispanic Black Men Living With Diabetes. Diabetes Education. 2016;42(3):325-35. Doi: $10.1177 / 0145721716640904$.

14. Taylor EE. Adolescents Food Choices and Its Impact on Their Health Status (A Case of Students in Dadease Agricultural Senior High Schools In Effiduase District). Doctoral Dissertation, University of Education, Winneba; 2017.

15. Santoso SO, Janeta A, Kristanti M, Perhotelan PM, Manajemen PS, Petra UK, et al. FaktorFaktor Yang Mempengaruhi Pemilihan Makanan Pada Remaja Di Surabaya. Jurnal Hospitality dan Manajemen Jasa. 2018;6(1).

16. Prakasam L. Assessment of $\mathrm{HbA} 1 \mathrm{C}$ of Adult Hispanics with Type 2 Diabetes in a FamilyCentered Nutritional Class. Brandman, California; 2017

17. Amuta $A O$, Mkuu $R$, Jacobs W, Barry $A E$. Number and Severity of Type 2 Diabetes among Family Members are Associated with
Nutrition and Physical Activity Behaviors. Front Public Health. 2017;5(1):157-63. Doi: 10.2289/ffubh.2017.00157.

18. Yang K, Baniak LM, Imes CC, Choi J, Chasens ER. Perceived Versus Actual Risk of Type 2 Diabetes by Race and Ethnicity. Diabetes Education. 2018; 25 (4). Doi: $10.1177 / 01457217187709831457217187709$ 83.

19. Darmon N, Drewnowski A. Contribution of Food Prices and Diet Cost to Socioeconomic Disparities in Diet Quality and Health: A Systematic Review and Analysis. Nutrition Review. 2015;73(10):643-60. Doi: 10.1093/nutrit/nuv027.

20. Triratnawati A. Makna Susu Bagi Konsumen Mahasiswa di Kafe Susu di Yogyakarta: Antara Gizi dan Gengsi. Jurnal Kesehatan Indonesia. 2017;14(1):27-35.

21. Hillier-Brown FC, Summerbell $C D$, Moore $H J$, Routen A, Lake AA, Adams J, et al. The Impact of Interventions to Promote Healthier Ready-toeat Meals (to eat in, to take away or to be delivered) Sold by Specific Food Outlets Open to the General Public: A Systematic Review. Obesity Review. 2017;18(2):227-46. Doi: 10.1111/obr.12479.

22. Seguin R, Connor L, Nelson M. Understanding Barriers and Facilitators to Healthy Eating and Active Living in Rural Communities. Journal of Nutrition 2014; 35(2): 23-25. Doi: $10.1155 / 2014 / 146502$.

23. Samuel-Hodge CD, Holder-Cooper JC, Gizlice Z, Davis G, Steele SP, Keyserling TC, et al. Family Partners in Lifestyle Support (PALS): Family-Based Weight Loss for African American Adults with Type 2 Diabetes. Obesity. 2017;25(1):45-55. Doi: 10.1002/oby.21700.

24. Martins J, Marques A, Sarmento $H$, Carreiro da Costa F. Adolescents' Perspectives on the Barriers and Facilitators of Physical Activity: A Systematic Review of Qualitative Studies. Health Education Research 2015, 30(5): 742-755. doi: 10.1093/her/cyv042.

25. Dimyati A. Materi Penyuluhan Tentang Sosialisasi Program Gerakan Masyarakat Hidup Sehat (Germas). Universitas Bandar Lampung. Bandar Lampung; 2017. 1-20 p.

26. George KS, Roberts CB, Beasley S, Fox M, Rashied-Henry K. Our Health is in Our Hands: A Social Marketing Campaign to Combat Obesity and Diabetes. American Journal of Health Promotion. 2016;30(4):283-6. Doi: $10.1177 / 0890117116639559$. 